\title{
GENDER DIFFERENCES IN PHYSICS ANXIETY AT A SOUTH AFRICAN UNIVERSITY
}

\author{
Leelakrishna Reddy \\ Department of Physics, University of Johannesburg (South Africa)
}

\begin{abstract}
From literature, it is known that anxiety for physics amongst female students appears to be higher than for male students. This study is carried out to determine the role that gender plays in their preference to physics and the anxiety they experience in the subject. To measure the anxiety that students experience in physics, use is made of a modified physics anxiety questionnaire, which was comprised of fifteen questions. This questionnaire has a rating scale from +1 (minimal anxiety) to +5 (very high anxiety). A total of 64 students participated in this study. Results for this study is presented both in numeric and in percentage form. From this study, it was revealed that female students have a significantly higher level of physics anxiety compared to their male counterparts. Besides the females having a higher level of anxiety in the thought of seeing their physics assessment marks, both males and females have a similar level of anxiety for the item relating to fear of failing their physics tests or examinations. Further, females appear to cringe in their behavior when they have to go to their physics classes. The anxiety experienced by male students is their desire to excel in the subject and thus they are more focused in their physics studies, while female students are overcome by the high cognitive demand of the subject and present a higher level of anxiety in the subject.
\end{abstract}

Keywords: Physics, gender, questionnaire and anxiety.

\section{Introduction}

Physics is feared as a difficult subject but how both males and females perceive it might be different. If the emotions of fear are not properly checked then this could lead to anxiety in physics amongst the students (Manilito et al, 2016). The net effect of all this is a lack of success and a perceived fear for the subject. Gender could be a factor in determining students' anxiety levels in physics (Manilito et al, 2016). This concept "anxiety" has a variety of meanings. According to Sapir \& Aronson (1990), Scovel (1991) and Sahin et al. (2015), anxiety is defined "as an unpleasant emotional state of uncertainty, fear, worry, discomfort, loss of control, and expectation that something bad will happen". In this context, anxiety is perceived as a feeling of fear or worry that something will happen. Such a variable could be responsible for their underperformance in the subject. In a sense anxiety could be their fear or discomfort in attending something challenging such as a test or an examination. Most of the time anxiety reveals itself as a positive or a negative construct. In a positive sense, anxiety can lead to an enhancement in learning (positive stress), while on the other hand, it can impede one's learning process (negative stress) (Sahin et al., 2015).

It is generally accepted, from literature, that male students significantly outperform their female counterparts in physics (Agra et al., 2017). However, some research points towards both males and females having similar anxiety levels in physics (Brownlow et al., 2000). A subject such as mathematics, which is the backbone of physics, is responsible for higher levels of anxiety amongst female students and can be regarded as a good predictor for gender prescriptor of anxiety levels (Devine et al., 2012; Agra et al., 2017). It is of interest to note that female students outperform their male counterparts in physics in the lower grades of school but that reverses itself in high school (Labudde et al., 2000; Sahin, 2015). Accordingly, this is reflected as lesser levels of physics anxiety for male students. Female students generally show avoidance for science-related subjects and indicative of a disregard or disinterest they have for the subject. 
According to literature, there is much research on mathematics anxiety and few researches on science anxiety and lesser research on physics anxiety (Agra et al., 2017), hence the aim of this paper is to shed more light on this topic with specific reference to the impact of physics anxiety as a function of gender.

\section{Research question}

What are the gender differences in physics anxiety amongst South African students?

\section{Methodology}

To measure students' anxiety levels in physics, use is made of a questionnaire called the "Physics Anxiety Questionnaire", downloaded from the website, which was uploaded by Jamie Bagundol on the $8^{\text {th }}$ September 2016 and retrieved from SCRIBD on the $2^{\text {nd }}$ May 2019. This questionnaire is comprised of fifteen items and scored on a Likert-type scale ranging from +5 (very high anxiety) to +1 (minimal anxiety). The participants in this study have enrolled for a six-month semester module (basic science in physics) in Emergency Medical Care and Podiatry at the University of Johannesburg in South Africa. With slight modifications to the original questionnaire, this questionnaire was then administered to 27 males $(42 \%)$ and 37 females (58\%). Thus, a total of 64 students participated in this study. The questionnaire itself consisted of some anxiety questions such as: "I sweated a lot whenever I took my physics exams/tests" and "I feared failing my physics exams/tests". Besides the questionnaire being given to elicit students' anxiety levels in physics, students' anxiety levels as a function of gender is also gathered. Before administrating the questionnaire, permission was sought from the students and an explanation as to why this research is done. Results are presented in both the numeric and percentage form. A higher percentage is reflective of a higher response and a greater anxiety towards physics.

\section{Results and discussions}

The results between the genders on the issue of anxiety levels in physics is shown in table 1 below.

Table 1. Differences in the anxiety levels between male and female students. Note that the categories very high anxiety and high anxiety levels have been combined, as well as partial and minimal anxiety. There is a total of 27 males and 37 females.

\begin{tabular}{|c|c|c|c|c|c|c|c|}
\hline \multirow[t]{2}{*}{ No } & \multirow[t]{2}{*}{ Physics anxiety } & \multicolumn{3}{|c|}{ Men } & \multicolumn{3}{|c|}{ Females } \\
\hline & & $\begin{array}{c}\text { Number: } \\
\text { Very high } \\
\text { anxiety to } \\
\text { high } \\
\text { anxiety }\end{array}$ & $\begin{array}{l}\text { Number: } \\
\text { Moderate } \\
\text { anxiety }\end{array}$ & $\begin{array}{l}\text { Number: } \\
\text { Partial to } \\
\text { minimal } \\
\text { anxiety }\end{array}$ & $\begin{array}{l}\text { Number: } \\
\text { Very high } \\
\text { anxiety to } \\
\text { high } \\
\text { anxiety }\end{array}$ & $\begin{array}{l}\text { Number: } \\
\text { Moderate } \\
\text { anxiety }\end{array}$ & $\begin{array}{c}\text { Number: } \\
\text { Partial to } \\
\text { minimal } \\
\text { anxiety }\end{array}$ \\
\hline \multirow[t]{2}{*}{1} & \multirow{2}{*}{$\begin{array}{l}\text { I was worried when I } \\
\text { was informed that } \\
\text { physics was a } \\
\text { requirement for my } \\
\text { course }\end{array}$} & 5 & 6 & 16 & 8 & 7 & 22 \\
\hline & & $19 \%$ & $22 \%$ & $59 \%$ & $22 \%$ & $19 \%$ & $59 \%$ \\
\hline \multirow[t]{2}{*}{2} & \multirow{2}{*}{$\begin{array}{l}\text { I felt a lot of } \\
\text { pressure/stress/burden } \\
\text { in my physics subject }\end{array}$} & 3 & 7 & 17 & 8 & 11 & 18 \\
\hline & & $11 \%$ & $26 \%$ & $63 \%$ & $22 \%$ & $30 \%$ & $49 \%$ \\
\hline \multirow[t]{2}{*}{3} & \multirow{2}{*}{$\begin{array}{l}\text { I felt my heartbeat } \\
\text { faster whenever I went } \\
\text { to my physics class }\end{array}$} & 1 & 1 & 25 & 3 & 6 & 28 \\
\hline & & $4 \%$ & $4 \%$ & $92 \%$ & $8 \%$ & $16 \%$ & $76 \%$ \\
\hline \multirow[t]{2}{*}{4} & \multirow{2}{*}{$\begin{array}{l}\text { I was worried about } \\
\text { being called in my } \\
\text { physics class }\end{array}$} & 2 & 4 & 21 & 7 & 3 & 27 \\
\hline & & $7 \%$ & $15 \%$ & $78 \%$ & $19 \%$ & $8 \%$ & $73 \%$ \\
\hline \multirow[t]{2}{*}{5} & \multirow{2}{*}{$\begin{array}{l}\text { I cringed when I had to } \\
\text { go to my physics class }\end{array}$} & 4 & 1 & 22 & 8 & 4 & 25 \\
\hline & & $15 \%$ & $4 \%$ & $81 \%$ & $46 \%$ & $11 \%$ & $67 \%$ \\
\hline
\end{tabular}




\begin{tabular}{|c|c|c|c|c|c|c|c|}
\hline \multirow[t]{2}{*}{6} & \multirow{2}{*}{$\begin{array}{l}\text { I felt uneasy when } \\
\text { asked to recite in my } \\
\text { physics class }\end{array}$} & 2 & 6 & 19 & 6 & 10 & 21 \\
\hline & & $7 \%$ & $22 \%$ & $70 \%$ & $16 \%$ & $27 \%$ & $57 \%$ \\
\hline \multirow[t]{2}{*}{7} & \multirow{2}{*}{$\begin{array}{l}\text { I could hardly } \\
\text { concentrate in my } \\
\text { physics class }\end{array}$} & 2 & 3 & 22 & 3 & 6 & 28 \\
\hline & & $7 \%$ & $11 \%$ & $82 \%$ & $8 \%$ & $16 \%$ & $76 \%$ \\
\hline \multirow[t]{2}{*}{8} & \multirow{2}{*}{$\begin{array}{l}\text { I could not do my } \\
\text { physics assignment } \\
\text { alone }\end{array}$} & 2 & 2 & 23 & 4 & 7 & 26 \\
\hline & & $7 \%$ & $7 \%$ & $86 \%$ & $10 \%$ & $19 \%$ & $71 \%$ \\
\hline \multirow[t]{2}{*}{9} & \multirow{2}{*}{$\begin{array}{l}\text { I had difficulty } \\
\text { understanding physics } \\
\text { concepts }\end{array}$} & 1 & 2 & 24 & 7 & 4 & 26 \\
\hline & & $4 \%$ & $7 \%$ & $89 \%$ & $19 \%$ & $11 \%$ & $70 \%$ \\
\hline \multirow[t]{2}{*}{10} & \multirow{2}{*}{$\begin{array}{l}\text { I could not sleep well } \\
\text { before every physics } \\
\text { test/exam }\end{array}$} & 1 & 6 & 20 & 11 & 2 & 24 \\
\hline & & $4 \%$ & $22 \%$ & $74 \%$ & $30 \%$ & $5 \%$ & $65 \%$ \\
\hline \multirow[t]{2}{*}{11} & \multirow{2}{*}{$\begin{array}{l}\text { I feared failing my } \\
\text { physics tests/exams }\end{array}$} & 10 & 3 & 14 & 14 & 8 & 15 \\
\hline & & $38 \%$ & $11 \%$ & $52 \%$ & $38 \%$ & $22 \%$ & $41 \%$ \\
\hline \multirow[t]{2}{*}{12} & \multirow{2}{*}{$\begin{array}{l}\text { I sweated a lot } \\
\text { whenever I took my } \\
\text { physics exams/tests }\end{array}$} & 3 & 5 & 19 & 6 & 7 & 24 \\
\hline & & $11 \%$ & $19 \%$ & $71 \%$ & $16 \%$ & $19 \%$ & $65 \%$ \\
\hline \multirow[t]{2}{*}{13} & \multirow{2}{*}{$\begin{array}{l}\text { My mind seems to go } \\
\text { blank during physics } \\
\text { assessments }\end{array}$} & 3 & 1 & 26 & 6 & 5 & 26 \\
\hline & & $11 \%$ & $4 \%$ & $85 \%$ & $16 \%$ & $14 \%$ & $71 \%$ \\
\hline \multirow[t]{2}{*}{14} & \multirow{2}{*}{$\begin{array}{l}\text { I fear to see my } \\
\text { assessment marks }\end{array}$} & 3 & 6 & 18 & 13 & 4 & 20 \\
\hline & & $11 \%$ & $22 \%$ & $67 \%$ & $35 \%$ & $11 \%$ & $54 \%$ \\
\hline \multirow[t]{2}{*}{15} & \multirow{2}{*}{$\begin{array}{l}\text { My fear of physics } \\
\text { makes me unable to } \\
\text { focus in class }\end{array}$} & 3 & 3 & 22 & 4 & 4 & 29 \\
\hline & & $11 \%$ & $11 \%$ & $78 \%$ & $11 \%$ & $11 \%$ & $79 \%$ \\
\hline
\end{tabular}

This study was undertaken to determine students' anxiety levels in physics as a function of gender. Analysis of the results reveals that there are gender differences in anxiety between males and females for the subject of physics. Females have a higher level of anxiety compared to the males. This concurs with the research undertaken by Anzi (2005), Mallow (1994), Udo et al. (2001) and Sahin et al. (2015). It is generally observed that male students have displayed minimal anxiety for most items of the questionnaire, except for item $11(38 \%)$ and below a moderate level for item $2(26 \%)$ in their anxiety levels for physics. For the females there appears to be a significantly higher levels of anxiety experienced by them in comparison to their male counterparts. In this respect, a relatively high level of anxiety was observed for items 5, 10, 11 and 14 in the questionnaire.

According to the males, their greatest fear is the fear of failing their physics tests or examinations. To a smaller extent, they appeared to worry about being informed that physics (non-major) was a requirement for their course curriculum. On a positive note, they have experienced partial to minimal anxiety for items in the questionnaire relating to their excitement in attending their physics classes (such as item 3, 92\%). For the female students, a similar but to a lesser level of anxiety was experienced (item 3, $76 \%$ ). Male students appear to be devoid of a cringe in their behavior when they must attend a physics class (item 5, 81\%). Their physical appearance appears to be one of excitement and not walking around with drooping heads. Such a behavior is not observed amongst the female students, where high levels of anxiety or stress was observed (item 5, 46\%) when they walked to their physics classes. Despite their differences in anxiety, both males and females display a high level of concentration when they are in a physics class (item 7, males $82 \%$ and females $76 \%$ ). On the aspect of understanding of physics concepts, the males take a lead in this regard and have a minimal anxiety (item 9, 89\%) while the females appear to lag slightly behind with a minimal anxiety level of $70 \%$ in this aspect. In terms of working independently, male students aim to work more independently than the females and this is reflected in their comparative anxieties for this item in the questionnaire (item 8 , males $86 \%$ and females 
71\%). A similar level of anxiety was observed for item 13, where students appear to be more focused and alert in class during physics assessments (males $85 \%$ and females $71 \%$ ). Likewise, both males and female students have little anxiety when it comes to being focused in class and thus have little fear for the subject and this is a little surprising for the female students (item 15: males $79 \%$ and females $78 \%$ ).

A relatively large number of female students (item 10,30\%) have sleepless nights before their physics assessments. In comparison with their male counterparts, it is observed that at least $74 \%$ of them are relatively more relaxed before such assessments. These anxiety levels amongst the females could be accountable for their underperformance in the subject. This item correlates well with item 11 for the females, in their fear of failing such assessments (38\%). A relatively small number of females appear to have minimal anxiety before such assessments (41\%). In this instance, at least half the male students also appear to have minimal anxiety levels before such tests and assessments (52\%). Another item, item 12 indicates that both genders appear to have sweated less when they took their physics tests or examinations (males $71 \%$ and females $65 \%$ ). In this respect, it means that they have experienced minimal anxiety during such assessments. A lack of sleep can be a positive or a negative factor in terms of test preparation. Some may be stressed to do well, or some may be stressed due to under preparation in the subject. In tandem to this item is item 14 , where $35 \%$ of the females appear to have a lot fear in seeing their assessments marks compared to the males where only $11 \%$ of them have such a fear. Of interest to this item is that $67 \%$ of the males have a minimal fear for observing their marks compared to $54 \%$ for the females.

Further analysis of the results reveals that females have particularly minimal levels of anxiety for three items of the questionnaire and they are items 3, 7 and 15. In comparison to the males, they have a relatively much higher percentage for most of these items except for item 15, meaning lesser anxiety levels. Item 3 when compared with item 2 reveals that despite the female students having a minimal fear of being in a physics class, they still have a moderate to high anxiety of the burden and stress of being in a physics class (about 50\%) compared to the males that have a minimal anxiety $(63 \%)$ of being in those classes. Surprisingly, both males and females have a similar level of anxiety (78\% for the males and $79 \%$ for the females) in the fear of the subject, which results in them being unable to focus. Despite all this, both males and females are always alert in class without their minds going blank during physics lessons (item 13: males $85 \%$ and females $71 \%$ ) and thereby experience minimal levels of anxiety. In terms of their confidence in the physics class, both genders appear to have great confidence in class, and this is reflected from the minimal anxiety scores between them for item 4 (item 4: males $78 \%$ and females $73 \%$ ).

However, if the students were required to recite in a physics class, the males would take the lead (item 6: males 70\%) and would have experienced a minimal amount of anxiety for this item compared to the females who would have rather experienced a little more stress (item 6: 57\%).

\section{Conclusion}

In this study, it is revealed that female students have a high level of physics anxiety than males and this inhibits their performance in physics. Physics anxiety is a complex construct (Sahin et al., 2015) and some of the factors such as learning skills (examination preparation) and their fear of failing or seeing their assessments appears to raise the anxiety levels of female students, while for the male students it is the fear of failing their physics tests or examination is which that raises their anxiety levels. The results of this study will contribute to a better understanding of anxiety amongst genders, which is important for physics practitioners.

\section{References}

Agra, E., Fischer, S. M., \& Beilock, S. L. (2017). The Role of Students' Gender and Anxiety in Physics Performance. American Association of Physics Teachers, $24-27$.

Brownlow, S., Jacobi, S., \& Rogers, M. (2000). Science anxiety as function of gender and experience. Sex Roles, 42(1-2), 119 - 131.

Devine, A., Fawcett, K., Szucs, D., \& Dowker, A. (2012). Gender differences in mathematics anxiety and the relation to mathematics performance while controlling for test anxiety. Behavioral and Brain Functions, 8(33), 33.

Labuddle, P., Herzog, W., Neuenschwander, M. P., Violi, E., \& Gerber, C. (2000). Girls and physics: teaching and learning strategies tested by classroom interventions in grade 11. International Journal of Science Education, 22(2), 143 - 157. 
Mallow, J.V. (1994). Gender-related science anxiety: Fear of Science and how to overcome it. New York: Van Nostrand Reinhold Company.

Manilito, A., Gardo, A., \& Elio, D. (2016). Physics anxiety, academic achievement and coping mechanism of sophomore bee students of the college of Teachers, Report in part fulfilment of an Educational Research in Physical Science, Education-Benquet State University, 1-73.

Sahin, M., Caliskan, S., \& Dilek, U. (2015). Development and Validation of the Physics Anxiety Rating Scale. International Journal of Environmental Education, 10(2), 183 - 200.

Sapir, S., \& Aronson, A. E. (1990). The relationship between psychopathology and speech and language disorder in neurological patients. Journal of Speech Hearing Disorders, 55, 503 - 509.

Scovel, T. (1991). The effect of affect on foreign language learning: A review of anxiety research. Language Learning, 28, 129 - 142.

Udo, M.K., Ramsey, G.P., Reynolds-Alpert, S., \& Mallow, J.V. (2001). Does physics teaching affect gender-based science anxiety? Journal of Science Education and Technology, 10(3), 237 - 247. 